\title{
Level of Anxiety-State as a factor in changing eating patterns in college students:
} \section{NUTSAU Study}

\author{
Nível de Ansiedade-Estado como um fator de mudança dos padrões alimentares em estudantes \\ universitários: Estudo NUTSAU
}

Nivel de Ansiedad-Estatal como factor en el cambio de patrones de alimentación en estudiantes universitarios: Estudio NUTSAU

Received: 12/21/2021 | Reviewed: 12/29/2021 | Accept: 12/30/2021| Published: 12/31/2021

\author{
Bruno dos Santos de Assis \\ ORCID: https://orcid.org/0000-0002-3939-6511 \\ Universidade Federal Fluminense, Brazil \\ E-mail: brunoassiscg@hotmail.com \\ Mariá Gonçalves Pereira da Silva \\ ORCID: https://orcid.org/0000-0003-0735-6280 \\ Universidade Federal do Estado do Rio de Janeiro, Brazil \\ E-mail: silvamgp@gmail.com \\ Camila Bastos Faustino \\ ORCID: https://orcid.org/0000-0001-6606-9877 \\ Universidade Federal do Estado do Rio de Janeiro, Brazil \\ E-mail: bastoscamilaf@gmail.com \\ Luana Azevedo de Aquino \\ ORCID: https://orcid.org/0000-0002-8785-2331 \\ Universidade Federal do Estado do Rio de Janeiro, Brazil \\ E-mail: aaquino.luana@gmail.com \\ Ana Beatriz Franco-Sena \\ ORCID: https://orcid.org/0000-0002-4196-1268 \\ Universidade Federal Fluminense, Brazil \\ E-mail: ab_franco@id.uff.br
}

\begin{abstract}
With the purpose of identifying eating patterns of university students at a federal university in the state of Rio de Janeiro, a cross-sectional analysis of food consumption data was stratified by anxiety symptom scores of 147 students enrolled in the second semester of several undergraduate courses in the second semester of 2015. The State-Trait Anxiety Inventory determined the anxiety symptoms scores. A food frequency questionnaire was applied to obtain food consumption data. Students were stratified into two groups, using the median state anxiety score as cutoff point. For each group, some dietary patterns were derived by the application of the principal component analysis. Statistical analysis was performed using the SPSS software. The university students presented a median state-anxiety score of 43 points, and it was significantly higher in women. Three dietary patterns were identified for each group according to their nutritional characteristics, among which "Mixed 1", "Healthy" and "Rice and Beans" for the less anxious students and "Western", "Mixed 2" and "Rice and Beans" for the most anxious students. The results showed that it was possible to identify consistent food patterns for both, using a factorial analysis method. Students with the highest anxiety-state scores had a pronounced Western eating pattern, and those least anxious students had higher consumption of healthier food groups and lower consumption of caffeinated beverages. Although this is a crosssectional analysis, it can contribute to optimize nutritional intervention for this population.
\end{abstract}

Keywords: Young adult; Factor analysis; Anxiety; Feeding behavior.

\section{Resumo}

Com o objetivo de identificar padrões alimentares de estudantes de uma universidade federal no estado do Rio de Janeiro, no segundo semestre de 2015, uma análise transversal de padrão de consumo foi estratificada em função do escore de sintomas de ansiedade de 147 estudantes do segundo semestre de diferentes cursos de graduação. O Inventário de Ansiedade Traço e Estado foi usado para definir os escores de ansiedade e um questionário de frequência alimentar foi aplicado na avaliação do consumo alimentar. Os participantes foram alocados em dois grupos, em função do valor mediano do escore de ansiedade-estado, onde foram identificados alguns padrões de consumo a partir da aplicação de análise de componentes principais. A análise estatística foi realizada utilizando o pacote R. Os participantes apresentaram escore de ansiedade-estado mediano de 43 pontos, sendo maior entre as mulheres. Três padrões de consumo foram identificados para cada grupo, considerando as características nutricionais 
dos alimentos consumidos, tais como: "Misto 1", "Saudável" e "Arroz e feijão" para os estudantes com menor ansiedade e "Ocidental", "Misto 2" e "Arroz e feijão" para os estudantes com maior ansiedade. Foi possível identificar padrões alimentares consistentes para ambos os grupos, usando o método da análise fatorial. Os estudantes com maiores escores de ansiedade-estado apresentaram, predominantemente, o padrão de consumo Ocidental e aqueles com menores escores relataram maior consumo de grupos de alimentos saudáveis e menor consumo de bebidas com cafeína. O presente estudo, apesar de transversal, pode contribuir para otimizar a intervenção nutricional para essa população.

Palavras-chave: Adulto jovem; Análise fatorial; Ansiedade; Comportamento alimentar.

\section{Resumen}

Con el fin de identificar patrones de alimentación de estudiantes de universidad federal del estado de Río de Janeiro, en el segundo semestre de 2015, se estratificó un análisis transversal de patrones de consumo según el puntaje de síntomas de ansiedad de 147 estudiantes de diferentes cursos de graduación. Se utilizó el Inventario de Ansiedad Rastro y Estado para definir las puntuaciones de los síntomas de ansiedad y se aplicó un cuestionario de frecuencia alimentaria para obtener datos sobre el consumo de alimentos. Los participantes se dividieron en dos grupos, según el valor mediano de la puntuación de ansiedad-estado, definido como el punto de corte. Para cada grupo, se identificaron algunos patrones de consumo a partir de la aplicación del análisis de componentes principales. El análisis estadístico se realizó utilizando el paquete estadístico R, con una puntuación media de ansiedad-estado de 43 puntos, siendo más alta entre las mujeres. Se identificó tres patrones de consumo para cada grupo ("Mixto 1", "Saludable" y "Arroz y frijoles" para alumnos con menos ansiedad y "Occidental", "Mixto 2" y "Arroz y frijoles" para alumnos con mayor ansiedad). Los resultados mostraron que fue posible identificar patrones dietéticos consistentes para ambos grupos. Los estudiantes con los puntajes de ansiedad estatales más altos tenían predominantemente el patrón de consumo occidental y aquellos con los puntajes más bajos informaron un mayor consumo de grupos de alimentos saludables y un menor consumo de bebidas con cafeína. El presente estudio puede contribuir a optimizar la intervención nutricional para esta población.

Palabras clave: Adulto joven; Análisis factorial; Ansiedad; Conducta alimentaria.

\section{Introduction}

Mental health problems represent a significant global burden of disease in all communities around the world (Paniccia et al., 2017). The prevalence rates of these illnesses are higher in university students compared to the general population, and anxiety is one of the most common issues (Tran et al., 2017).

Anxiety is defined as feelings of excessive worry, restlessness, easy tiredness, concentration problems and difficulty in sleeping (Sena, 2014). The absence of treatment, especially in adolescents and young adults, can lead to several complications, such as increased risk of cardiovascular disease, weight gain in adulthood and sleep disorders (Sena, 2014; Mahmoud et al., 2015; Roest et al., 2010; Whiteford et al., 2015). For these groups, some milestones, as the admission to university, may influence new behaviors and social relationships as well as the anxiety that can turn food into a "refuge" in situations of physical and mental stress (Soar et al., 2012).

The eating habits of the adolescents and young adults are commonly characterized by a low consumption of fruits and vegetables (Feitosa et al., 2010), easy access to industrialized foods and high-calorie fast foods (Petribú et al.,, 2009), and highfrequency of away-from-home meals, which are mostly less healthy compared to home-cooked meals (Duarte et al., 2013). An analysis of the food consumption of a sample of Brazilian university students showed low adherence to eight of the ten steps for an adequate and healthy diet proposed by the national guideline (Souza \& Backes, 2020). In terms of evaluation of the eating habits, the most reliable way consists in a dietary pattern analysis that characterizes the evaluation of a set of food groups commonly consumed by individuals and populations (Diez \& Frayze-Pereira, 1999; Willet, 1998).

In a study conducted in Brazil, the dietary pattern of 125 nutrition-science graduate students of the State of Bahia was evaluated. The dietary pattern named "Traditional" consisted of the roots/berries, vegetables, dairy products, meats and eggs, natural fruit/juice and vegetables food groups; the "Exam Days" pattern was composed of breads/cereals, sausages and artificial drinks; the "End of Semester" pattern was characterized predominantly by sweets/sugars and snacks and the pattern "Anxiety" was composed of coffee/tea and fats (Pereira-Santos et al., 2016). 
The identification of dietary patterns enables the determination of the food groups' characteristics, the stage of life and the period of the course of study which is considered challenging for the welfare of the students (Ludwig et al., 2015) and may trigger a change in their academic performance, thinking ability, memorization and interest in learning (Torquato et al., 2010).

Despite the importance to evaluate the relationship between the food patterns of university students and their mental health, there are still few publications in this area. The development of studies that identify specific patterns for different groups of students could optimize nutritional intervention, especially considering the importance of associating food consumption with their anxiety profile. Therefore, the goal of the present study was to identify the dietary patterns of university students, at a federal university in the state of Rio de Janeiro, according to their level of anxiety.

\section{Methodology}

This is a observational cross-sectional study analysis of a quantitative sample of adolescents and adults accompanied by the Study of Nutrition Science and Health in University Students - NUTSAU, in the laboratory of the Center for Health Research and Society (NUPESS/UFRJ-Macaé). The 147 participants were enrolled in the second academic semester of all seven undergraduate majors (Biology, Nursing, Engineering, Pharmacy, Nutrition Science, Medicine and Chemistry) at the Federal University of Rio de Janeiro, Macaé Campus.

This sample was chosen because the academic activities of these undergraduates-were concentrated on campus upon admittance and in the second semester of the year. The students are already acquainted with the campus, since they have already experienced the university for at least six months, having therefore already adapted their food routine to the new moment of their lives (Perez et al., 2016).

The data collection was carried out during the second half of 2015, in the classrooms and laboratory of the Center for Health Research and Society (NUPESS/UFRJ-Macaé), by trained researchers associated to the NUTSAU. The data collection happened in the beginning of the classes in which researchers guided the students to self-fill-in the questionnaire.

The instrument for data collection consisted of a self-completion questionnaire based on instruments usually applied in epidemiological studies (Brasil, 2017; Matsudo et al., 2001; Sichieri \& Everhart, 1998; Spilberger et al., 1983) composed by questions regarding social demographic data, nutritional status, assessment of anxiety and food consumption.

The socioeconomic status of university students was evaluated by socio-demographic issues, using the classification criteria of the Brazilian Association of Research Companies (ABEP, 2014), which are based on the calculation of existing goods at home (household appliances and cars), the presence of a maid and the schooling of the head of the family. Additionally, information about age, (years) housing (alone, with family, friends) and scholarships (Scientific Initiation, Extension, Housing, Neither) was also obtained.

Body mass $(\mathrm{kg})$, height $(\mathrm{cm})$, waist circumference $(\mathrm{cm})$ and body fat $(\%)$ were collected and measured according to standardized methodology proposed by Lohman, Roche \& Martorell (1988) in the NUPESS laboratory by trained researchers to determine the nutritional status. Body mass was measured with a Tanita Inner Scan® digital scale, with precision of $50 \mathrm{~g}$ and maximum capacity of $150 \mathrm{~kg}$ with the individual standing barefoot on the scale platform and wearing light clothing. Height was measured using the Alturaexata ${ }^{\circledR}$ portable stadiometer, with $1 \mathrm{~cm}$ precision. The Body Mass Index (BMI) was calculated from the division of the individual's body mass by their height squared $\left(\mathrm{kg} / \mathrm{m}^{2}\right)$ and classified according to the categories proposed by the World Health Organization (WHO, 2007) for adolescents ( $<20$ years) and adults ( $\geq 20$ years).

The waist circumference (WC) was obtained with a non-extensible tape measure, positioned at the midpoint between the last rib and the prominence of the iliac crest and read at the time of expiration (Lohman et al., 1988). The measurement was classified as adequate (less than $94 \mathrm{~cm}$ for males and less than $80 \mathrm{~cm}$ for females), as risk for cardiovascular diseases (values 
from $94 \mathrm{~cm}$ for males and from 80 for females) and as increased risk for cardiovascular diseases (values from $102 \mathrm{~cm}$ for males and from 88 for females), according to the WHO proposition (2000).

The body fat was evaluated using the bipolar lower limb electrical bioimpedance. Tanita Inner Scan ${ }^{\circledR}$ equations were used to calculate the percentage of body fat and the classification proposed by Lohman (1992) were adopted.

For the anxiety assessment, it was applied the State and Trace Anxiety Inventory scale (IDATE) proposed by Spielberger and contributors in 1983. IDATE is a self-reported instrument with scores for individual questions which are answered to describe how the individual usually feels (almost never, coded by 1 ; sometimes, coded by 2 ; often, coded by 3 ; almost always, coded by 4). The IDATE-E, which consists of 20 questions (Spielberger et al., 1983; Biaggio, Natalicio \& Spielberger, 1977), was adopted to obtain an anxiety-state score of each participant. Finally, the participants were gathered by their score of anxiety state, classified as equal or greater versus lower than the median value (Zhang et al., 2019; Hepp et al. 2016).

Aiming at the identification of the dietary patterns, it initially obtained the students' food consumption data, through the application of a previously validated semi-quantitative food frequency questionnaire (FFQ) proposed by Sichieri and Everhart (1998) with 72 foods or preparations. In the FFQ, there were eight consumption frequency options, ranging from "never" or "almost never" to "more than three times a day". The reported frequency of intake was later transformed into daily frequency and the total daily consumption was calculated for each individual. The items listed in the FFQ were organized based on their similarity into some food groups' variables, nutritional characteristics and their probable influence in anxiety behavior.

In order to verify if the food groups' variables could relate to characterized dietary patterns (factors), a factorial analysis was applied. This analysis was separately applied to each anxiety group, aiming at verifying whether this characteristic could differ from dietary patterns. The extraction of the factors was carried out through the principal component analysis (PCA). The criterion used to define the number of factors was the scree-plot test, pointed before the main curve inflection (Hair et al., 2009; Mingoti, 2005).

After defining the number of factors, it was performed the Varimax rotation to obtain a structure that keeps each factorial load greater than 0.3. To verify if the resultant factorial model was suitable for these data, the Kaiser-Meyer-Olkin (KMO) and the Barlett's sphericity tests were applied. The model was considered suitable when the KMO was greater than 0.6 and the p-value was lower than 0.05 for the Barlett's sphericity hypothesis. Finally, the internal consistency of each factor was verified using Cronbach's alpha, considering values above 0.6 as proper grouping of elements for each one (Mingoti, 2005; Kac et al., 2007). Each factor was named as a dietary pattern based on its food groups' variables.

\subsection{Data Analysis}

Descriptive analysis of the main variables was performed in order to determine the characteristics of the sample. To test the normality of the numerical variables, Kolmogorov-Smirnov and Shapiro-Wilk tests were applied. The numerical variables were presented as median and interquartile interval, and the comparison between the groups through the MannWhitney test. The categorical variables were presented as frequencies and the comparison between groups used the Chi-square test. The significance level adopted was 0.05 . The software SPSS, version 20 was used for the processing and statistical analysis. 


\subsection{Ethical aspects}

The study complies with the criteria of Resolution number 466 of December 12, 2012, of the National Health Council in addition to being approved by the Research Ethics Committee of the Federal University of Rio de Janeiro - Macaé Campus (CAAE 51104115.4.0000.5699).

All the participants were informed about the purposes of this study and then were asked to sign the Consent Form.

\subsection{Author Contributions}

All authors contributed for the conception and outline of this study. The preparation of the manuscript and analysis of data were done by Bruno dos Santos de Assis, Luana Azevedo de Aquino, Ana Beatriz Franco-Sena, Camila Bastos Faustino and Mariá Gonçalves Pereira da Silva. The first draft of the manuscript was written by Bruno dos Santos de Assis and all authors commented and assisted in all versions of the manuscript, and all approved the final version.

\section{Results}

The group of 147 students presented a median value of 19 years old, with a range from 17 to 25 years old. Almost $64 \%$ of the students enrolled were health-related majors (Biology, Nursing, Pharmacy, Nutrition Science and Medicine), of which $83 \%$ were females, expressively different from the percentage of males ( $p$-value $\leq 0.05$ ). Among these students, 53.1\% lived with their families and $91.8 \%$ were not granted university scholarships. In relation to the nutritional status, $25.8 \%$ of the students were inadequate and $7.5 \%$ classified as obese. Regarding the waist circumference, $8.2 \%$ of those present values that suggest risk for cardiovascular diseases and $22.4 \%$ had greater percentage of body fat than recommended. Considering the non-normality of the data, the results were expressed by a median, P25 and P75 (Table 1).

Table 1. Characteristics of the study participants.

\begin{tabular}{|c|c|c|c|c|}
\hline Variables & $\begin{array}{c}\text { Total } \\
(\mathrm{n}=147)\end{array}$ & $\begin{array}{c}\text { Female } \\
(n=93)\end{array}$ & $\begin{array}{c}\text { Male } \\
(n=54)\end{array}$ & \\
\hline Weight $(\mathrm{Kg})$ & $62.5(53.9-70.9)$ & $57.3(51.4-64.8)$ & $69.7(61.1-78.2)$ & $*$ \\
\hline Height (cm) & $166.4(160.6-173.6)$ & $162.2(157.4-166.4)$ & $174.9(172.8-177.4)$ & $*$ \\
\hline Anxiety-state score & $43.0(38.0-51.0)$ & $45.0(39.0-54.0)$ & $41.0(36.0-46.0)$ & $*$ \\
\hline Courses & & & & $*$ \\
\hline Health-related major & $94(63.9 \%)$ & $77(82.8 \%)$ & $17(31.5 \%)$ & \\
\hline Engeneering/Math & $53(36.1 \%)$ & $16(17.2 \%)$ & $37(68.5 \%)$ & \\
\hline \multicolumn{5}{|l|}{ Living } \\
\hline Alone & $19(12.9 \%)$ & $11(11.8 \%)$ & $8(14.8 \%)$ & \\
\hline With family & $78(53.1 \%)$ & $51(54.8 \%)$ & $27(50 \%)$ & \\
\hline With friends & $50(34 \%)$ & $31(33.3 \%)$ & $19(35.2 \%)$ & \\
\hline \multicolumn{5}{|l|}{ Grant aid } \\
\hline Yes & $12(8.2 \%)$ & $9(9.7 \%)$ & $3(5.6 \%)$ & \\
\hline No & $135(91.8 \%)$ & $84(90.3 \%)$ & $51(94.4 \%)$ & \\
\hline \multicolumn{5}{|l|}{ BMI } \\
\hline Underweight & $3(2 \%)$ & $1(1.1 \%)$ & $2(3.7 \%)$ & \\
\hline Normal range & $109(74.1 \%)$ & $71(76.3 \%)$ & $38(70.4 \%)$ & \\
\hline Overweight & $24(16.3 \%)$ & $13(14 \%)$ & $11(20.4 \%)$ & \\
\hline Obesity & $11(7.5 \%)$ & $8(8.6 \%)$ & $3(5.6 \%)$ & \\
\hline \multicolumn{5}{|l|}{ Body fat } \\
\hline Excellent/Good & $43(29.3 \%)$ & $21(22.6 \%)$ & $22(40.7 \%)$ & \\
\hline Above/Middle/Low & $71(48.3 \%)$ & $49(52.7 \%)$ & $22(40.7 \%)$ & \\
\hline Bad/Very Bad & $33(22.4 \%)$ & $23(24.7 \%)$ & $10(18.5 \%)$ & \\
\hline
\end{tabular}

*Significant p-value. Weight, height and anxiety-state score results are expressed by Median (P25-P75). The other variables, by the absolute and relative frequency. Source: Authors. 
Gathering the 72 FFQ items resulted in 17 food groups' variables (Table 2). Some items like fresh fish, rice, beans and coffee were not gathered since they are frequent products in the regional diet. The PCA was applied to these 17 food groups' variables, resulting in three factors for both anxiety-state score students group.

Table 2. Grouping of items present in the FFQ in the food groups' variables.

\begin{tabular}{|c|c|}
\hline Food groups' variables & Item in the FFQ \\
\hline Rice & Rice \\
\hline Sugary drinks & Guarana-based soft drink; Fruit Juice or Fruit Pulp; Cola-based soft drink; Sugar; Mate tea \\
\hline Coffee & Coffee \\
\hline Carbohydrates & $\begin{array}{l}\text { Noodles; Lasagna/Gnocchi/Ravioli; Cake; French Bread or Sliced Bread; Cassava Flour; Polenta or Angu (corn-meal } \\
\text { puree); Cassava or Manioc; Boiled Potatoes or Mashed Potatoes; Savory Biscuits }\end{array}$ \\
\hline Meat & Pork; Chicken; Beef; \\
\hline Comfort food & $\begin{array}{l}\text { Pizza; Chips or Fried Grated Potatoes; Snack Foods; Popcorn; Deep-fried Snacks (Fried Salty); Ice cream; Chocolate } \\
\text { Bar or Candy; Milk Jam; Sandwich Cookie }\end{array}$ \\
\hline Sweets & Hard Candy; Cocoa Powder and Instant Chocolate Mix; Fruit Jam; Cookies \\
\hline Packed and canned & Sausage; Wiener; Cold cuts; Bacon or Bacon; Hamburger; Canned Sardine or Tuna \\
\hline Beans & Beans \\
\hline Fruits & Orange or Tangerine; Banana; Papaya; Apple; Watermelon or Melon; Pineapple; Mango; Grape \\
\hline Fats & Mayonnaise; Butter or Margarine; Peanut \\
\hline Vegetables & Tomato; Cucumber; Chayote; Carrot; Beetroot \\
\hline Milk and dairy products & Cheese; Cream cheese; Milk; Yoghurt \\
\hline Eggs & Fried egg; Boiled egg \\
\hline Fish & Fresh Fish \\
\hline Vegetables & Pumpkin; Cabbage or Broccoli; Zucchini; Okra; Green bean \\
\hline Leaflets & Lettuce; Collard greens; Cabbage \\
\hline
\end{tabular}

Source: Authors.

For anxiety-state score lower than the median the KMO statistics was 0.61 , and 0.69 for anxiety-state score greater than the median. The Barlett's sphericity test, in both scenarios, showed sufficient and adequate correlation between the data of factorial model $(\mathrm{p}<0.01)$. In all derived dietary patterns, regardless of the group of anxiety, it was possible to verify sufficient internal consistency (Cronbach's alpha higher than 0.6) (Table 3 and Table 4). 
Table 3. Factorial loads estimated for each food pattern for anxiety state below the median group.

\begin{tabular}{|c|c|c|c|}
\hline Food groups' variables & Mixed 1 & $\begin{array}{l}\text { Food Patterns } \\
\text { Healthy }\end{array}$ & Rice/Beans \\
\hline Carbohydrates & 0.70 & 0.05 & 0.13 \\
\hline Cold cuts / canned food & 0.67 & 0.12 & 0.31 \\
\hline Comfort food & 0.67 & -0.22 & 0.01 \\
\hline Sweets & 0.60 & -0.24 & 0.13 \\
\hline Fats & 0.59 & -0.05 & -0.29 \\
\hline Meat & 0.53 & 0.29 & 0.53 \\
\hline Eggs & 0.53 & 0.50 & 0.09 \\
\hline Milk and dairy products & 0.50 & 0.11 & 0.10 \\
\hline Fish & 0.44 & 0.28 & -0.35 \\
\hline Coffee & -0.39 & 0.10 & -0.01 \\
\hline Root Vegetables & 0.03 & 0.81 & 0.16 \\
\hline Leafy vegetables & -0.26 & 0.75 & 0.13 \\
\hline Seeded Vegetables & -0.20 & 0.66 & -0.13 \\
\hline Fruits & 0.18 & 0.64 & -0.19 \\
\hline Beans & -0.05 & -0.11 & 0.77 \\
\hline Rice & 0.07 & -0.04 & 0.74 \\
\hline \multicolumn{4}{|l|}{ Sugary drinks } \\
\hline Cronbach's alpha & 0.74 & 0.71 & 0.70 \\
\hline
\end{tabular}

For those students with the anxiety-state score below the median, the derived dietary patterns were named Mixed 1 ( $21.1 \%$ of variability); Healthy (15.4\% percent of variability) and Rice/Beans (10.5\% of variability), which could explain $47 \%$ of the total variability in the food consumption (Table 3).

For the students with scores equal or greater than the median, derived dietary patterns were Western $(27.4 \%$ of variability), Mix 2 (13.2\% of variability) and Rice/Beans (9.5\% of the variability), which could explain $50.1 \%$ of the food consumption variability (Table 4).

Table 4. Factorial loads estimated for each food pattern for anxiety state above the median group.

\begin{tabular}{lccc}
\hline \multicolumn{1}{c}{ Food Groups } & Western & $\begin{array}{c}\text { Food Patterns } \\
\text { Mixed 2 }\end{array}$ & Rice/Beans \\
\hline Comfort food & 0.82 & 0.04 & 0.16 \\
Sweets & 0.73 & -0.04 & 0.24 \\
Canned food & 0.70 & 0.13 & -0.07 \\
Carbohydrates & 0.69 & 0.31 & 0.36 \\
Fats & 0.65 & 0.05 & 0.10 \\
Sugary drinks & 0.65 & 0.19 & -0.39 \\
Coffee & 0.42 & 0.04 & 0.23 \\
Fruits & -0.19 & 0.80 & 0.27 \\
Root Vegetables & 0.36 & 0.71 & -0.17 \\
Seeded Vegetables & 0.13 & 0.65 & 0.24 \\
Leafy vegetables (Leaflets) & -0.01 & 0.58 & 0.40 \\
Eggs & 0.03 & 0.58 & -0.11 \\
Fish & 0.02 & 0.44 & -0.36 \\
Meat & 0.24 & 0.37 & 0.08 \\
Milk and dairy products & 0.29 & 0.35 & 0.23 \\
Beans & 0.18 & 0.08 & 0.79 \\
Rice & 0.33 & 0.21 & 0.63 \\
Cronbach's alpha & 0.84 & 0.83 & 0.82 \\
\hline
\end{tabular}

\section{Discussion}

The present study presented three main results: 1) female university students presented higher anxiety-state scores than male students; 2) the predominant dietary pattern identified in the students presents consonance with the pattern usually called Western; and 3) substantially different dietary patterns were identified within the different anxiety-state groups. 
College time is considered a stressful period, being a challenge to the personal well-being state of the students (Pereira-Santos et al., 2016). Factors such as addictions, professors' demands, individual habits and academic responsibilities (Ludwig et al., 2015) are usually associated with this moment of important decision making (Chen et al., 2013). Anxiety is one of the most common symptoms as a response to stress and factors such as financial issues, simultaneous study and work, reduction of sleeping time, excessive study burden, accomplishment of many assignments, meeting family expectations and seeking employment after graduation from higher education are provocative (Dehghan-Nayeri \& Adib-Hajbaghery, 2011). University students, when compared to the other population groups, show a greater propensity to gain weight, resulting in changes starting from the admission to the university, to changes in eating patterns, physical activity, stress, and the consumption of alcohol and tobacco $(\mathrm{Bu}, 2013)$.

In this study, approximately $24 \%$ of the sample was overweight or obese, with no significant difference regarding gender. In contrast, the self-reported anxiety-state score was significantly higher in women. Previous studies showed that hormonal cyclical changes besides genetic predisposition could act as a trigger for mental health changes such, as anxiety in women (Blaine, 2008). Additionally, the poor safety problem in Brazil, family pressure and dietary impulses due to daily anxiety, create great consequences in this gender, being therefore the most anxious population (De Wit et al., 2019; Marmorstein et al., 2014).

Especially for women, this moment of life, when university students may be called young adults and the early years of the undergraduate courses represent a transitional period in their lives, it is marked by vulnerability and important life-long decisions (Chen et al., 2013). Combined with new behaviors and social relationships, physical and mental stress situations, as well as anxiety, can turn food into a "refuge" influencing eating habits into the consumption of specifically food groups, such as ultra-processed foods (Soar et al., 2012; Matos et al., 2013).

In Brazil, the contribution of consumption of ultra-processed foods due to the daily energy consumption is $20.3 \%$ for women, while it is $19.1 \%$ among men. Regarding the age group, the contribution is of $19.5 \%$ of ultra-processed foods among the adult population (IBGE, 2020a). According to the data from the National Health Survey (PNS) recently released, $24.6 \%$ of young adults, between 18 and 24 years old, reported intake of at least 5 groups of ultra-processed foods the day before the interview (IBGE, 2020b). Along these lines, the influence of these foods in the population's habitual diet is confirmed, contributing to the characterization of the Western food pattern (Bielemann et al., 2015).

Derivations of dietary patterns, through the principal component analysis, carried out in other food surveys showed similar results to the present study, where it was possible to identify patterns predominantly denominated Western or fast-food, followed by those denominated healthy or prudent or traditional local (Willett, 1998; Morinaka et al., 2013; Wang et al., 2011).

Western pattern is mainly composed by foods with high energy density, both sweet and/or savory, which are the preferred food of young people who are emotionally unstable and may adopt counter-regulatory eating behaviors to soften their emotions, leading to greater consumption of foods with greater palatability due to the neuronal stimuli they cause (Keller $\&$ Siegrist, 2015). Consequently, a diet rich in foods with a high fat and sugar content causes inflammatory cognitive alterations, leading to health deterioration (Morris et al., 2015). The consumption of sugary beverages, soft drinks and non-carbonated sugary beverages, for example, can cause health problems due to the amount of excessive sugar present in these formulations (Sampasa-Kanyinga et al., 2018), which can further aggravate the levels of anxiety in those who already have or lead to the development of this health problem (Soar et al. 2012).

In animal model studies, it was identified that the associated consumption of sucrose and caffeine in rats may model the preference for choosing energy drinks and soft drinks, which may justify the frequency of consumption in this group, and that intermittent access to these products increases anxiety (Xu \& Reichelt, 2018). Still in animal models, Western style eating 
habits, with diets rich in saturated fats and mixed in sugars, sucrose and glucose, could contribute to the relevance of anxiety symptoms (Peris-Sampedro et al., 2019).

The relationships between mental health and the use of caffeine include claims of improved physiological functioning, with the consumption of coffee usually being a strategy to alleviate the stress arising from academic routine (Ríos et al., 2013). Previous studies showed that consumption could provide short-term improvements in mood and performance in relation to well-being, vitality, symptoms of depression and anxiety (Wesnes et al., 2013). On the other hand, there may also be increased nervousness and insomnia (Salinero et al., 2014).

The Western dietary pattern is characterized by a high consumption of meats,-sausages and vegetable oils (used in food preparation). The high consumption of vegetable oils (such as soy and sunflower oils) is associated with a reduced omega-3 content in the body (Blasbalg et al., 2011).

On the other hand, fish is one of the sources of high biological value, easily digested proteins, which contain essential amino acids. They are a source of polyunsaturated fatty acids, particularly omega-3 fatty acids, important throughout life and consumed mainly in the form of fresh fish and fish oil supplements, capable of reducing the risk of cardiovascular disease and protecting the nervous system (Swanson et al., 2012). Previous studies suggested a modulating effect on brain communication by the consumption of fish (Mischoulon \& Freeman, 2013). The modification of the tissue lipid composition of the cell membrane and the production of lipid mediators (Rodrigues et al., 2014), reduce anxiety by regulating the response to stress (Morgese et al., 2017).

Thus, increased consumption of fish, especially of marine origin, can generate positive effects for human healthy (Strobel et al., 2012), different from what is proposed in the Western dietary pattern.

\section{Conclusion}

The use of principal component analysis to derive the dietary patterns of university students can be considered a contribution of this study to this area, since there are few studies in this population group. In addition, derivation of dietary patterns stratified by groups with lower and higher anxiety profiles is a first step to identify occasional dietary habit changes of these students, which may guide discussions on the relationship between food intake and the levels of anxiety presented by these young adults.

In relation to potential limitations of the study, the cross-sectional character of the study could be highlighted, which can complicate the inferences regarding the causality and direction of the association. Although the sample size was small, it was possible to derive patterns that met the necessary premises after factor analysis.

The stratification of the sample according to the median of the anxiety score-enabled identifying potential differences in consumption pattern among groups with more and less symptoms of anxiety.

Especially in the most anxious individuals, the Western dietary pattern was more pronounced, and in those less anxious students, the Mixed dietary pattern. Some items of the Western pattern characterized the Mixed Pattern, but the addition of food groups with high biological proteins value, fresh fish and no caffeinated beverages, could suggest the differences in anxiety levels.

Therefore, for future studies, we suggest the possibility of a longitudinal study to observe the deeper connection between anxiety and food patterns.

\section{Acknowledgments}

We are grateful to everyone who directly and indirectly contributed to the completion of the article. 


\section{Funding}

This research did not receive any specific grant from funding agencies in the public, commercial, or not-for-profit sectors.

C.B.F received a scholarship from Brazilian National Council for Scientific and Tecnological Development (CNPq).

\section{Conflict of interests}

The authors declare no conflict of interests.

\section{Transparency declaration}

The lead author affirms that this manuscript is an honest, accurate, and transparent account of the study being reported; that no important aspects of the study have been omitted; and that any discrepancies from the study as planned have been explained. This work was reported according to the Strengthening the Reporting of Observational Studies (STROBE) guidelines.

\section{References}

Associação Brasileira de Empresas de Pesquisa (2014). Critério de Classificação Econômica Brasil - CCEB. https://www.abep.org/criterio-brasil

Biaggio, A. M. B., Natalício, L., \& Spielberger, C. D. (1977). Desenvolvimento da forma experimental em português do Inventário de Ansiedade TraçoEstado (IDATE) de Spielberger. Arquivos brasileiros de psicologia aplicada, 29(3), 31-44.

Bielemann, R. M., Motta, J. V. S., Minten, G. C., Horta, B. L., \& Gigante, D. P. (2015). Consumption of ultra-processed foods and their impact on the diet of young adults. Revista de saude publica, 49, 28.

Blaine, B. (2008). Does depression cause obesity? A meta-analysis of longitudinal studies of depression and weight control. Journal of health psychology, 13(8), 1190-1197.

Blasbalg, T. L., Hibbeln, J. R., Ramsden, C. E., Majchrzak, S. F., \& Rawlings, R. R. (2011). Changes in consumption of omega-3 and omega-6 fatty acids in the United States during the 20th century. The American journal of clinical nutrition, 93(5), 950-962.

Brasil. (2018) Ministério da Saúde. Secretaria de Vigilância em Saúde. Departamento de Vigilância de Doenças e Agravos não Transmissíveis e Promoção da Saúde. Vigitel Brazil 2017: surveillance of risk and protective factors for chronic diseases by telephone survey: estimates of Frequency and sociodemographic distribution of risk and protective factors for chronic diseases in the capitals of the 26 Brazilian states and the Federal District in 2017. https://bvsms.saude.gov.br/bvs/publicacoes/vigitel_brasil_2017_vigilancia_fatores_risco_1ed_rev.pdf

Bu, S. Y. (2013). Transitional changes in energy intake, skeletal muscle content and nutritional behavior in college students during course-work based nutrition education. Clinical Nutrition Research, 2(2), 125-134.

Chen, L., Wang, L., Qiu, X. H., Yang, X. X., Qiao, Z. X., Yang, Y. J., \& Liang, Y. (2013). Depression among Chinese university students: prevalence and socio-demographic correlates. PloS one, 8(3), e58379.

De Wit, L., Luppino, F., van Straten, A., Penninx, B., Zitman, F., \& Cuijpers, P. (2010). Depression and obesity: a meta-analysis of community-based studies. Psychiatry research, 178(2), 230-235.

Dehghan-Nayeri, N., \& Adib-Hajbaghery, M. (2011). Effects of progressive relaxation on anxiety and quality of life in female students: a non-randomized controlled trial. Complementary therapies in medicine, 19(4), 194-200.

Diez Garcia, R.W., \& Frayze-Pereira, J. A. (1999) A comida, a dieta, o gosto: mudança na cultura alimentar urbana. Master's Thesis, Universidade de São Paulo

Duarte, F. M., de Almeida, S. D. S., \& Martins, K. A. (2013). Alimentação fora do domicílio de universitários de alguns cursos da área da saúde de uma instituição privada. O mundo da Saúde, 37(3), 288-298.

Feitosa, E. P. S., Dantas, C. D. O., Andrade-Wartha, E. R. S., Marcellini, P. S., \& Mendes-Netto, R. S. (2010). Hábitos alimentares de estudantes de uma universidade pública no Nordeste, Brasil Food habits of students of one public university of Northeast, Brazil. Alimentos e Nutrição Araraquara, 21(2), 225230 .

Fonseca, L. B., Pereira, L. P., Rodrigues, P. R. M., Andrade, A. D. S., Muraro, A. P., Gorgulho, B. M., \& Ferreira, M. G. (2021). Food consumption on campus is associated with meal eating patterns among college students. British Journal of Nutrition, 126(1), 53-65.

Hepp, P., Hagenbeck, C., Burghardt, B., Jaeger, B., Wolf, O. T., Fehm, T., \& Schaal, N. K. (2016). Measuring the course of anxiety in women giving birth by caesarean section: a prospective study. BMC pregnancy and childbirth, 16(1), 1-7. 
Hair, J. F., Black, W. C., Babin, B. J., Anderson, R. E., \& Tatham, R. L. (2009). Análise multivariada de dados. Bookman editora.

Instituto Brasileiro de Geografia e Estatística (2020a). Coordenação de Trabalho e Rendimento (2020) Pesquisa nacional de saúde: percepção do estado de saúde, estilos de vida, doenças crônicas e saúde bucal: Brasil e grandes regiões. https://biblioteca.ibge.gov.br/visualizacao/livros/liv101764.pdf

Instituto Brasileiro de Geografia e Estatística (2020b). Coordenação de Trabalho e Rendimento (2020) Pesquisa de orçamentos familiares 2017-2018: análise do consumo alimentar pessoal no Brasil. https://biblioteca.ibge.gov.br/visualizacao/livros/liv101742.pdf

Kac, G., Sichieri, R., \& Gigante, D. P. (2007). Epidemiologia nutricional. Editora Fiocruz.

Keller, C., \& Siegrist, M. (2015). Does personality influence eating styles and food choices? Direct and indirect effects. Appetite, 84, $128-138$.

Lohman, T. G. (1992). Advances in body composition assessment. Human Kinetics, 1-23.

Lohman, T. G., Roche, A. F., \& Martorell, R. (1988). Anthropometric standardization reference manual. ed. Champaign IL: Human Kinetics Books.

Ludwig, A. B., Burton, W., Weingarten, J., Milan, F., Myers, D. C., \& Kligler, B. (2015). Depression and stress amongst undergraduate medical students. BMC medical education, 15(1), 1-5.

Mahmoud, J. S., Staten, R. T., Lennie, T. A., \& Hall, L. A. (2015). The relationships of coping, negative thinking, life satisfaction, social support, and selected demographics with anxiety of young adult college students. Journal of Child and Adolescent Psychiatric Nursing, 28(2), 97-108.

Marmorstein, N. R., Iacono, W. G., \& Legrand, L. (2014). Obesity and depression in adolescence and beyond: reciprocal risks. International journal of obesity, 38(7), 906-911.

Matos, I. B., Toassi, R. F. C., \& Oliveira, M. C. D. (2013). Profissões e ocupações de saúde e o processo de feminização: tendências e implicações. Athenea digital: revista de pensamiento y investigación social. Barcelona. 13(2), 239-244.

Matsudo, S., Araújo, T., Marsudo, V., Andrade, D., Andrade, E., \& Braggion, G. (2001). Questinário internacional de atividade f1 sica (IPAQ): estudo de validade e reprodutibilidade no Brasil. Rev. bras. ativ. fís. saúde, 05-18.

Mischoulon, D., \& Freeman, M. P. (2013). Omega-3 Fatty Acids in Psychiatry. Psychiatr Clin North Am 36:15-23

Mingoti, S. A. (2005). Análise de dados através de métodos de estatística multivariada uma abordagem aplicada. Editora UFMG, Belo Horizonte

Morgese, M. G., Tucci, P., Mhillaj, E., Bove, M., Schiavone, S., Trabace, L., \& Cuomo, V. (2017). Lifelong nutritional omega-3 deficiency evokes depressivelike state through soluble beta amyloid. Molecular neurobiology, 54(3), 2079-2089.

Morinaka T., Wozniewicz M., Jeszka J., J. Bajerska, Nowaczyk P., \& Sone Y. (2013). A ocidentalização dos padrões alimentares entre as jovens japonesas e polonesas - um estudo comparativo. Anais da Medicina Agrícola e Ambiental. 2013; 20 (1): 122-130

Morris, M. J., Beilharz, J. E., Maniam, J., Reichelt, A. C., \& Westbrook, R. F. (2015). Why is obesity such a problem in the 21st century? The intersection of palatable food, cues and reward pathways, stress, and cognition. Neuroscience \& Biobehavioral Reviews, 58, 36-45.

Paniccia, M., Paniccia, D., Thomas, S., Taha, T., \& Reed, N. (2017). Clinical and non-clinical depression and anxiety in young people: A scoping review on heart rate variability. Autonomic Neuroscience, 208, 1-14.

Perez, P. M. P., Castro, I. R. R. D., Franco, A. D. S., Bandoni, D. H., \& Wolkoff, D. B. (2016). Práticas alimentares de estudantes cotistas e não cotistas de uma universidade pública brasileira. Ciência \& Saúde Coletiva, 21, 531-542.

Peris-Sampedro, F., Mounib, M., Schéle, E., Edvardsson, C. E., Stoltenborg, I., Adan, R. A., \& Dickson, S. L. (2019). Impact of free-choice diets high in fat and different sugars on metabolic outcome and anxiety-like behavior in rats. Obesity, 27(3), 409-419.

Petribú, M. D. M. V., Cabral, P. C., \& Arruda, I. K. G. D. (2009). Estado nutricional, consumo alimentar e risco cardiovascular: um estudo em universitários. Revista de Nutrição, 22(6), 837-846.

Ríos, J. L., Betancourt, J., Pagán, I., Fabián, C., Cruz, S. Y., González, A. M., \& Palacios, C. (2013). Caffeinated-beverage consumption and its association with socio-demographic characteristics and selfperceived academic stress in first and second year students at the University of Puerto Rico Medical Sciences Campus (UPR-MSC). Puerto Rico health sciences journal, 32(2).

Rodrigues, P. O., Martins, S. V., Lopes, P. A., Ramos, C., Miguéis, S., Alfaia, C. M., \& Prates, J. A. (2014). Influence of feeding graded levels of canned sardines on the inflammatory markers and tissue fatty acid composition of Wistar rats. British journal of nutrition, $112(3), 309-319$.

Roest, A. M., Martens, E. J., de Jonge, P., \& Denollet, J. (2010). Anxiety and risk of incident coronary heart disease: a meta-analysis. Journal of the American College of Cardiology, 56(1), 38-46.

Salinero, J. J., Lara, B., Abian-Vicen, J., Gonzalez-Millán, C., Areces, F., Gallo-Salazar, C., \& Del Coso, J. (2014). The use of energy drinks in sport: perceived ergogenicity and side effects in male and female athletes. British Journal of nutrition, 112(9), 1494-1502.

Sampasa-Kanyinga, H., Hamilton, H. A., \& Chaput, J. P. (2018). Sleep duration and consumption of sugar-sweetened beverages and energy drinks among adolescents. Nutrition, 48, 77-81.

Sena, T. (2014). Manual diagnóstico e estatístico de transtornos mentais-DSM-5, estatísticas e ciências humanas: inflexões sobre normalizações e normatizações. INTERthesis: Revista Internacional Interdisciplinar, 11(2), 96-117. 
Research, Society and Development, v. 10, n. 17, e252101725040, 2021

(CC BY 4.0) | ISSN 2525-3409 | DOI: http://dx.doi.org/10.33448/rsd-v10i17.25040

Sichieri, R., \& Everhart, J. E. (1998). Validity of a Brazilian food frequency questionnaire against dietary recalls and estimated energy intake. Nutrition Research, 18(10), 1649-1659.

Soar, C., de Sousa Silva, P., \& Lira, J. G. (2012). Consumo alimentar e atividade física de estudantes universitários da área de saúde. Revista Univap, 18(31), 41-47.

Souza, R. K. D., \& Backes, V. (2020). Autopercepção do consumo alimentar e adesão aos Dez Passos para Alimentação Saudável en tre universitários de Porto Alegre, Brasil. Ciência \& Saúde Coletiva, 25, 4463-4472.

Spielberger, C. D., Goruch, R. L., Lushene, R. E., Vagg, P. R., \& Jacobs, G. A. (1983). Manual for the state-trait inventory STAI (form Y). Mind Garden, Palo Alto, CA, USA.

Strobel, C., Jahreis, G., \& Kuhnt, K. (2012). Survey of n-3 and n-6 polyunsaturated fatty acids in fish and fish products. Lipids in health and disease, 11(1), 110 .

Swanson, D., Block, R., \& Mousa, S. A. (2012). Omega-3 fatty acids EPA and DHA: health benefits throughout life. Advances in nutrition, 3(1), 1-7.

Torquato, J. A., Goulart, A. G., Vicentin, P., \& Correa, U. (2010). Avaliação do estresse em estudantes universitários. InterSciencePlace, 1(14).

Tran, A., Tran, L., Geghre, N., Darmon, D., Rampal, M., Brandone, D., \& Avillach, P. (2017). Health assessment of French university students and risk factors associated with mental health disorders. PloS one, 12(11), e0188187.

Wang, S. F., Mu, M., Zhao, Y., Li, H. Z., Fang, Y. F., Wang, H. L., \& Hu, C. L. (2011). Dietary patterns and its influencing factors among freshmen students in college. Zhonghua liu xing bing xue za zhi= Zhonghua liuxingbingxue zazhi, 32(9), 869-872.

Wesnes, K. A., Barrett, M. L., \& Udani, J. K. (2013). An evaluation of the cognitive and mood effects of an energy shot over a $6 \mathrm{~h}$ period in volunteers. A randomized, double-blind, placebo controlled, cross-over study. Appetite, 67, 105-113.

Whiteford, H. A., Degenhardt, L., Rehm, J., Baxter, A. J., Ferrari, A. J., Erskine, H. E., \& Vos, T. (2013). Global burden of disease attributable to mental and substance use disorders: findings from the Global Burden of Disease Study 2010. The lancet, 382(9904), 1575-1586.

Willett, W. C. (2018) . Nutritional Epidemiology. OUP USA; 1998. https://doi.org/10.1093/acprof:oso/9780195122978.001.0001

World Health Organization (2007) Growth reference data for 5-19 years. http://www.who.int/growthref/en/.

World Health Organization (2000) Obesity: preventing and managing the global epidemic: report of a WHO consultation. Geneva, 2000. https://apps. who.int/iris/handle/10665/37003

Xu, T. J., \& Reichelt, A. C. (2018). Sucrose or sucrose and caffeine differentially impact memory and anxiety-like behaviours, and alter hippocampal parvalbumin and doublecortin. Neuropharmacology, 137, 24-32.

Zhang, J., Liu, X., \& Fang, L. (2019). Combined effects of depression and anxiety on suicide: A case-control psychological autopsy study in rural China. Psychiatry research, 271, 370-373. 